\title{
La Imagen Total. Forma y Espacio Público Ampliado
}

\author{
René JARA R. \\ Hans STANGE M.
}

\section{Uno}

El espacio público. Surgido al alero del sujeto moderno, ilustrado. Un lugar para ejercer el derecho de participar activamente de la construcción social, para instalar un sentido sobre la realidad de esto social. Un lugar donde confluyen individuos racionales y discursos sobre la Modernidad. Espacio de disputa por la instalación de sentidos hegemónicos sobre la interpretación de lo real.

Durante siglos, el cruce entre sujetos públicos y discursos públicos acontece en la palabra. El texto reina, otorgando sentido, espesor y verdad. La Postmodernidad acaba con este reinado: se proclama el fin de las utopías, la emergencia de un nuevo paradigma, las transformaciones de la sociedad de consumo, la muerte del individuo, la suspensión de la temporalidad y de la historicidad, reemplazados por un presente perpetuo; la radical mutación del signo en puro significante, de las profundidades en superficies. Es la desustancialización de lo real.

¿Acontece, entonces, una disolución del espacio público en la Postmodernidad? Lo que surgió como ámbito de diferenciación de lo privado, esfera política de negociación entre el mundo civil y el Estado, se define más allá de la dicotomía en la que lo instala la Ilustración: aparece como un lugar de conflicto del cual sujetos y discursos pretenden apropiarse, como un lugar de mediaciones entre los distintos agentes de la cultura. Ciertamente, el espacio público no es aquel ilustrado: es el espacio público construido por nuevos sujetos totales - publicitados, privatizadores-, por nuevas formas culturales -la imagen-, vehiculizado por nuevos formatos -la televisión.

\footnotetext{
René Jara y Hans Stange cursan actualmente la Licenciatura en Comunicación Social del Instituto de la Comunicación e Imagen, Universidad de Chile.
} 
La Postmodernidad amplió las posibilidades en la construcción del sentido, precipitándonos hacia nuevos modos de comprensión, interpretación y elaboración de la realidad. En el espacio público, nuevos formatos adquieren hegemonía en la disputa por la significación y desplazan la antigua centralidad de la palabra.

\section{Dos}

Postmodernidad: continuidad con la Modernidad. Apenas se nos prometió que las condiciones históricas, políticas y culturales anunciaban la realización de las promesas de la Razón y el advenimiento del individuo y los discursos, las lógicas de producción cultural cambiaron las coordenadas de comprensión. Sociedad de consumo, industria cultural, capitalismo financiero, fracaso de los proyectos revolucionarios: nuevas reglas que ponen en cuestión la linealidad de los relatos, la progresión de los procesos. Algo ocurre en el lenguaje. Ya no basta la palabra, el texto suena a vacío, no comunica. Nuevos regimenes de significación se articulan en torno a nuevos modos de expresión, escriturales, visuales. Hay cambios: en las nociones de tiempo y espacio -de inmediatez y perdurabilidad-, en nuestra fe en los relatos y mitos del mundo, en las identidades, en los individuos.

La Postmodernidad: el verdugo de todo lo sagrado y profundo del imperio de la letra. Pero decir esto es afirmar un juicio axiológico en el que han caído, por igual, revolucionarios de viejo lomo, conservadores y antiglobalizadores. ¿ Existe tal ruptura, el fin del lugar seguro, el declive del poder de los sabios de ordenar el mundo por medio de la palabra?

Esta ruptura -el fin de los metarrelatos de Lyotard, la personalización de lo público en Lipovetsky, la muerte del Aura benjaminiana, el signo vuelto puro significante de Cuadra- no es tal. Los cambios en la cultura occidental son cambios comunicacionales, que expresan la emengencia de nuevos niveles en la construcción de sentido, en los conceptos de tiempo y espacio, en la construcción de sujetos e identidades. Y lo que acontece es la ineficiencia de los modelos teóricos y las baterfas conceptuales para dar cuenta, describir y explicar estos cambios, estas nuevas dimensiones alcanzadas por nuestra cultura.

La semiologización aparece como un proceso que pone en evidencia nuevos niveles de sentido, más allá de la articulación del signo como significa-

30 do/ significante, e incluso más allá de su disolución en puro significante: la capacidad de transformar todo en materia de sentido, de prescindir de los símbolos para fundar un orden. Más aún, de volver todo un signo de algo.

La psicologización, por otro lado, da cuenta de un nuevo tipo de sujeto -y con êl, de nuevos niveles en la construcción de su publicidad y su identi- 
dad-más allá de la dicotomfa ilustrada de lo público y lo privado: sujeto total que privatiza los espacios comunes atrayéndolos hacia su intimidad y que publicita su privacidad, manifestándose públicamente en ella. Sujeto que no disuelve estas posiciones opuestas, sino que las interconecta y dinamiza.

Si acaso hay una ruptura, es la de los límites y márgenes de las formas de nuestra cultura, principalmente de los textos y discursos. Pero incluso estas rupturas son comprendidas como una superación constante de los niveles de espacio y tiempo de los productos culturales. Descentramientos: aquello central deviene marginal y reelabora nuevos centros en la configuración simbólica del mundo. Los límites se desplazan, los polos se multiplican y lo que aparece como fragmentación, no es más que una hiper-interconexión de los elementos, nuevas rutas para los flujos en disputa, nuevas posibilidades para instalar y producir sentido. El trabajo en el confin: la tarea de la superación de las categorfas clásicas de espacialidad y temporalidad: la emergencia de nuevos sentidos no-narrativos.

La Postmodernidad: lo que emerge son nuevas dimensiones en la estructuración de los sentidos, antes que una fragmentación o una crisis del dispositivo moderno. El descentramiento como campo para nuevas posibilidades de significación. ¿Por qué hablar entonces de ruptura?

\section{Tres}

La hermeneutica: una ontologia del sentido. Hasta el estructuralismo, no concebimos el sentido de un producto cultural sino como una propiedad inherente a él mismo, como parte de su esencia. Dice Jameson (1988): "leemos la cláusula entera y de la interrelación de sus palabras o significantes se deriva un significado más global, ahora llamado un "significado-efecto". El significado, tal vez incluso la ilusión o el espejismo del significado y del sentido en general, es un efecto producido por la interrelación de significantes materiales."

Sentido articulado. La significación como un efecto articulado de sentido, problema de formatos y formantes, antes que de contenidos. Nuevos niveles de tiempo y espacio, nuevas reglas de construcción: nuevos modos de significar. La ruptura entre Modernidad y Postmodernidad aparece, más bien, como el surgimiento de nuevas estrategias, sintaxis y protocolos de percepción en la elaboración de sentidos, en donde la centralidad de la letra es disputada por nuevas formas.

La forma: expresión de una relación social, huella de un cambio social. Término conceptual y operativo, propiedad y cosa, la forma es el entretejido en el que confluyen semánticas, sintaxis y pragmáticas, usos y procesos socio-históricos, condiciones materiales de producción simbólica y matrices 
conceptuales para su puesta en acto. La forma: el dispositivo articulador de sentido, bajo ciertas condiciones materiales, sociales, culturales.

La forma es también un eje problemático en la reflexión sobre Postmodernidad, de incidencia relevante en la percepción de una ruptura paradigmática. La forma plantea un problema de aproximación metodológica. Sus intentos de descripción u operativización -desde los estudios culturales, la semiótica, la estética o la teoría literaria - no develan su carácter primordial en los procesos de significación, a nivel estructural. La academia opta por el texto para inteligibilizar sujetos, discursos y procesos. Pero el texto es sólo una forma más. La pertinencia de la investigación académica en lo textual -no en lo formal-es inaplicable a las nuevas formas emergentes. "Retórica de la imagen", "texto audiovisual", "narrativa visual": nada más descabellado.

La palabra: una forma como otras. Central en un tiempo, disputa hoy en "igualdad de condiciones" la articulación de sentidos con otras formas que adquieren preeminencia. Su calda no es el fin del sentido, de la historia ni el advenimiento del vacío. Desplazamiento postmoderno: nuevos niveles que operan bajo los mismos mecanismos y tratamientos de la producción cultural. Nuevas formas instalan nuevos sentidos, sin avasallar con nada, como temen los hijos de la letra.

\section{Cuatro}

La crisis del espacio público, espacio de disputa "textual". La ruptura no es tal: esconde un proceso continuo de incorporación de nuevas formas en la contienda por instalar sentidos hegemónicos, no sólo textuales. Lo que aparece como disolución del espacio público es la ampliación de los campos de lucha a sentidos articulados sobre la base de otros tiempos, otras dimensiones espaciales, que superan las dicotomías instaladas por la razón -como lo público/privado, lo individual/colectivo, lo racional/pasional-, al tiempo que acentúan la tendencia más importante de la Modernidad: la construcción del individuo.

Nuevos espacios públicos: nuevos actores sociales. La ampliación de la disputa de sentido hacia formas no textuales implica la transformación de los sujetos en contienda. Surge un individuo hedonista, consumista, "psi", que, sin embargo, está urgido por expresarse públicamente, por participar de un mundo social reducido a lo privado, a lo comunitario, desconfiado de

32 | las instituciones públicas, pero no del espacio de disputa. Sujeto total: privado en lo público, público en lo privado, articulador de nuevos espacios de disputa hechos a medida de las nuevas formas en uso.

Sociedades de consumo: articuladas en torno a reglas constitutivas de orden comunicacional. Sprachspielen e imágenes erigidas como nueva habla 
social. Las nuevas formas expresan nuevas relaciones sociales que devienen de la cultura textual, la integran y la reciclan formalmente, depurándola, acentuando algunas tendencias y obviando otras. Postmodernidad: recambio de la Modernidad, no su crisis.

¿Cuáles son las nuevas formas que se integran al espacio público, en la lucha por el sentido? La imagen. Forma autonomizada desde las vanguardias, sustentada en sí misma, no-referencial, articulando procesos de significación a partir de sus propias condiciones de existencia, hablando de sí misma, llenándose de sentido -negando, por tanto, su vacío, delicia de apocalípticos.

En la arena del espacio público, la letra toma su lugar entre muchas otras contendientes, y lo que conocimos como sujetos y palabras han travestido en narcisos e imágenes.

\section{Cinco}

El espacio público: lugar de disputa por la instalación de sentidos hegemónicos, articulados por dispositivos culturales de producción y significación: las formas. Postmodernidad: momento en que la forma "texto" cede su hegemonía a la forma "imagen" en los modos de significación, en un proceso continuo -no rupturista- que importa cambios en las nociones de tiempo, espacio e identidad: la época del sujeto narcisista, pulsional, notextual y, sin embargo, hijo de la Modernidad.

Instalación de sentidos hegemónicos, formas totales: el problema de la articulación de sentidos es, preferentemente, un problema de formatos. En el campo de disputa de las significaciones, los nuevos niveles de sujetos, formas y dimensiones estructurales emergen de las caracteristicas de los soportes que las posicionan, y que tienden a anular su referencialidad para erigirse a sí mismos como articuladores de orden y significancia. Un cambio de formato es un cambio en la forma cultural: un cambio en la relación social que ésta expresa y en el sentido que así se articula.

El espacio público: un lugar de mediaciones entre formas puestas en formato: espacio de sentidos mediatizados y mediatizadores. La "puesta en forma", el auge de los géneros: la reelaboración y creación de formatos como acto de significación.

La instalación de la imagen como forma central en la redefinición de los espacios públicos, es al mismo tiempo la instalación del formato audiovisual como el central en la vehiculización de los sentidos en disputa. El reino de la imagen es el de la televisión, y su reinado lleva, así como ocurrió con la letra en el siglo XVIII, a la "televisación" del espacio público. 
La imagen es una forma total. Autónoma, capaz de hablar sólo de sí misma y a partir de ella. Es también totalitaria: formatea a sus contendientes y los subsume. La prensa se transforma en dominio de lo televisual, en su crónica. La televisión misma se transforma en su biógrafa, recursiva, autorreferente, abandonando toda referencialidad y des-ordenando las dicotomías de la Modernidad. El espacio público postmoderno: muchas formas y sentidos en disputa, pero un solo formato imperando: el de la imagen televisual.

\section{Seis}

El espacio público postmoderno: dominio de la imagen total. Los discursos se comprenden desde los formatos, ampliando las posibilidades de producción y significación de los campos de disputa, antes que provocando su disolución. Espacio de mediaciones y televisación: la imagen instala sentidos coherentes, hegemónicos y autonomizados de toda referencia, propagando una imagen de sí misma como soporte del proceso de significación. El espacio público acontece en la televisión y, por tanto, en plazas, bares y en la intimidad del hogar. El régimen de la imagen: la posibilidad de conexión de todos los mundos posibles, la anulación de las dicotomías ilustradas, la hiper-circulación de formas y sentidos.

Nuevos espacios públicos: nuevos sujetos, nuevos discursos, nuevos sentidos, nuevos formatos. Más que su crisis, la ampliación de sus procesos y dispositivos hasta límites insospechados. Efectos de sentido total, que atrapan todas las otras formas. Dominio coercitivo de la imagen televisual, sí, pero condición de posibilidad para contener cualquier propuesta de sentido que sea formada en imagen. Dictadura del formato televisual: hegemonía de la forma visual: espacio para la circulación total.

\section{Referencias bibliograficas}

Arfuch, Leonor: Lo Público y lo Privado en la Escena Contempordnea: Politica y Subjetividad. En: Revista de Critica Cultural, Santiago de Chile, Nov. 2000. Benjamin, Walter: La Obra de Arte en la Época de su Reproductibilidad Técnica. En: Discursos Interrumpidos, I, Editorial Taurus, Buenos Aires, 1989. Calabrese, Omar: La Era Neobarroca, Editorial Cátedra, Madrid, 1999.

34 Cuadra, Alvaro: De la Ciudad Letrada a la Ciudad Virtual. En: www.labrechadigital.org, Santiago de Chile, 2003.

Cuadra, Álvaro: La Ciudad sin Rostros. En: Ossa, Carlos (compilador): La Pantalla Delirante, Editorial LOM-Arcis, Santiago de Chile, 1999.

Del Villar, Rafael: Nueva Cultura Audiovisual y Protocolos Interpretativos. En: Ossa, Carlos (compilador): La Pantalla Delirante, Editorial LOM-Arcis, Santiago de Chile, 1999. 
Foucault, Michel: Nietzsche, Marx, Freud. Editorial Espíritu Libertario, Santiago de Chile, 2003.

Gazitúa, Mattas; Jara, René; Stange, Hans: ¿La Condición Postmoderna?, 2002. Gramsci, Antonio: Antologta, Siglo Veintiuno Editores, Ciudad de México, 1970. Jameson, Fredric: Posmodernismo y Sociedad de Consumo. En: Foster, Hal (compilador): La Postmodernidad, Editorial Colofón, Ciudad de México, 1988. Kant, Immanuel: ¿Qué es la Ilustración? En: Filosofia de la Historia, Fondo de Cultura Económica, Ciudad de México, 1979.

Lipovetsky, Gilles: La Era del Vacio, Editorial Anagrama, Barcelona, 1986 (decimotercera edición: 2000).

Lyotard, Jean-François: La condicion Postmoderna, Editorial Cátedra, Madrid, 1987.

Martín-Barbero, Jesús: De los Medios a las Mediaciones, Editorial Gustavo Gili, Barcelona, 1987.

Martín-Barbero, Jesús: Los Descentramientos del Arte y la Comunicacion. En: Ossa, Carlos (compilador): La Pantalla Delirante, Editorial LOM-Arcis, Santiago de Chile, 1999.

Santa Cruz, Eduardo: El Imperio de lo Verosimil (o el Periodismo Moderno Travestido de Marketing Informativo). En: Ossa, Carlos (compilador): La Pantalla Delirante, Editorial LOM-Arcis, Santiago de Chile, 1999.

Williams, Raymond: Sociologia de la Cultura, Editorial Paidós, Barcelona, 1994. 
